測定法

講 座

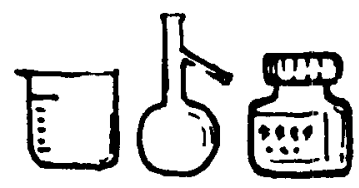

1 はじめに

電気化学測定法は，金属電極（液体金属を含む）上で 起こる電気化学反応を追跡するための手法として高度な 水凖にまで発達し，今日では多くの分野で重要な測定技 術の一つとして定着しつつある。これは，電気化学が異 相接触界面で起こる化学エネルギーと電気エネルギーと の間の相互变換および関与する (帯電) 物質同士の相互 作用を対象とする学問であり，物質系を限定したもので はないためである。したがって，電気化学は，物質系を 対象上する学術分野と谷易にクロスオーバーさせること ができるので, 電気化学で取り扱う系す無限に拡がって いる，金属電極を用いて溶解種放るいは吸着種を対象上 する場合の電気化学測定法については，すでに多くの著 書(4)で詳しく述べられているので，本稿では，インサー ション材料を対象とした電気化学測定法にっいて実践的 な立場から述べてみたい。

\section{2 インサーション材料の特徵}

電解質溶液と接している固体マトリックスに系外から 電子を注入する（系外に電子を取り出す）と固体は負 （止）に带電し，電子とイオンが固体/液体界面で刘峙す る状況が生まれる．この時，何等かの電何補償がなされ なければ，固体/液体界面は次第に分極される。一方， このような状況下の固体/液体界面で, 注入(出)された 電子と等価の電荷補償が円滑に行われれば，分極仕著し く低減される。この電荷補償の能力を減極能と云い，己 の能力を示す物質を減極剂とよぶ，多くの場合，固体マ トリックスの分解によって電荷補償が行わ机るか，ある いは電解質溶液中に存在する化学種が固体マトリックス 上でこの役割を演じることによって電荷補償か行われる. 従来の第一種電極，第二種電極，(溶解種の）レドック 又電極，ガス電極がこれに相当する ${ }^{5)}$. しかし，これら の電極系のよ゙れにも属さない比較的新しい電極系がイン サーション電極である。すすおわち，固体/液体の物理界 面を介してリチウムイオンや水素イオンなどのカチオン

大阪书立大学工学部応用化学科（元558 大阪市住吉区杉本 3-3138)
を固体のマクロな形態を保ちながら出し入れすることに よって電荷補償が行われ, 結果として材料の化学組成老 連続的に変化させることによって固体減極剤として働く ような材料である。このような材料を総称してインサー ション材料之呼んでいる, ${ }^{6,7)}$. 結晶性固体からなるイン サーション材料で結晶の基本骨格を保持したまま進行す る反応をトポタクティック反応之呼ぶままた，層状化合 物のインサーション反応でステージ生成を伴うものをイ ンターカレーション反応と呼んでいる，電池機能材料を 考える上で重要な材料招よび反応様式である，いずれの 場合にも，インサーション反応が進行する際には，特殊 な場合を除いて固体マトリックスの体積が変化する。し たがって，この新しい電極系を構成するインサーション 材料を取り扱う場合には，従来の電気化学測定技術に加 えて，この体積の膨張・収縮を考虑した上で，電極，七 ル，計測機器なよ゙を構築する必要がある。

\section{3 電極の構成}

興味深い電極挙動から研究を通じてインサーション材 料であることを確認できる材料の形態は，ほとんぞ全て が粉体である、したがって，この粉体を用いて通常の電 極形態とすることがまず必要となる，この時，材料に何 を，どの程度期待するか似よって，その取扱い，得られる情 報の質が異なる。取り扱う材料の予備的な検討として

（1）粉体のみを压縮成型した電極を用いて，電解酸化・ 還元が可能かどうか, 電極形態・色調の変化の有無を直 接観察する,

（2）粉体に導電剂（通常，アセチレンブラック，黒鉛 などの炭素材）を加えて（合剂），圧縮成型し，これを 電極として (1)の挙動之比較検討する。また，必要なら ば合剂の配合比を変える,

（3）電極挙動を追跡する際に柔軟性が必要ならば，(2 の合剤組成に更に結着剤を加えて，見たい現象あるいは 目的とするキャラクターが再現できる条件を挆る。また， 必要に応じて結着㸞の種類を検討する,

などが少なくとも必要である。これらの予備的な検討結 果から目的に適った電極を構成することが可能となる. 
しかし，この電極構成は，研究の目的に依存するので， これを一義的に論じることは不可能に近い.

リチウム塩を溶解させた非プロトン性有機溶媒を電解 液に用いて，これらの電極挙動を検討する上，

(a) 見かけ上電解液に濡れているにも関わらず，厚み のある電極の隅々まで電解液が浸透しないので再現性が 得られない,

(b) 材料によっては，あまり高い温度がかりられず， 減圧下゙で例えば脱酸素などによる材料の組成変化などで, 厚みのある多孔体電極内の残留水分を取り除くことが難 しく，得られた情報が水素イオン・エレクトロン反纫系 の香のなのか, リチウムイオン・エレクトロン伩応系の あのなのかがはっきりしない,

(c) 電解液を入れるまでは電極形状を保っているにも かかわらず，注液後，電極が膨れてしまって初期に設定 した電極形状が乱れ，時として電極心㗔，割れ，剥離な よ゙によって正確な情報が得られない， などの多孔体 (粉体) 電栖固有のトラブルが見受けられる.

これらの対策として, 注液方法の改良, 注液後の静琹 時間の変更, 電解液の選択, 合剤組成㧍よび形状の收底, 後述する試験用セルの改良などがある. 目的を電池機能 材料に限定して実験条件を設定する場合には，多くの充 電・放電曲線を一枚の図に表し，複数個のデータがほぼ 一本の曲線己なる条件を再現性の尺度しして，その時の 材料が示す最高容量を条件設定することが望ましい。こ の時，必ず負極に金属りチウムを用いて作動電压を测定 し，充電あるいは放電容量を正極（負極）材料 $1 \mathrm{~g}$ 当た りの容量に換算して表す（一般には $\mathrm{mAh} \cdot \mathrm{g}^{-1}$ ) のが既 い. また, 天科の精度, 実験に要する時間などを加味し て誤差の生じにくい条件を見つけておくこと李基礎研究 の過程では特に重要である，厚みのある電極の全ての粒 子に電子を供給すると共に電解液を保持させるために用 いるアセチレンブラックなどの導電剂, 作業性を改善し, 電極形状を保つために用いるテフロンなどの絬着珴は, 目的に応じて必要最小限とすることが望ましい，多くの 場合，これらを用いない方が正確な基礎データが得られ るので，材料のキャラクターに応じた電極構成とするこ とが何よりも重要である。

\section{4 電気化学セルの構造}

通常の電気化学測定用のセルは，作用桠，ルギン毛管 付き参照電極，対極，ガラスあるいはテフロン製の電解 槽から構成される．作用極の構造を「夫することによっ て，このセルを用いてインサーション材料を検討するこ よができる，多量の電解液を必要とするので，このよう なセルをフラッデッド三電極セルと呼んでいる。このガ ラス製のセルを用いると，作用極上での材料の色の变化 電極形態の変化, 電極上でのガス発生, 電解液の色調変
化を直接観察できる，と云う長所がある。しかし，

(1) 作用極の膨れ・剥離・変形なよ゙の形態変化のため データの再現性を確保するのが難しい,

（2）電解液量が多く，必然的に電解液中に存在する水 分の総量が多くなるので，この水分との競合作用によっ て生じる副反応などで, 正確な情報が得られない, なよ゙の欠点がある.

これらの欠点を改良するためにアルミニウムなどのエ クスパンデッドメタルシートに炭素材と結着剤を若干増

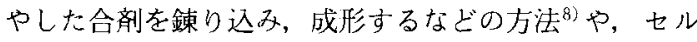
を工夫して電解液量を減らすなどの方法が支る。しかし， 多くの場合，このフラッデッド三電極セルは，信頼性に こしく，可逆電極機能を検討する際には特に注意を要する.

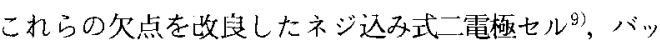
グ式二電極セル ${ }^{10)}$, 密閉加圧式二電極セル11)なよ゙があ る. Fig. 1 に泌閉加厌式一電極セルの構造を示す．こ のセルは,

(1) 電解液が比較的小量 $\left(0.1 \sim 0.2 \mathrm{~cm}^{3}\right.$ 程度) ですむ ので，混入水分の総量が少なく，これによる曖味さが少 ない,

（2）多孔質膜を介した二枚の電極は，バネで若干加圧 状態にしてあるので，電極の膨張あるいは収縮によるト ラブルが少ない,

（3）ほぼ完全な密閉状態を保てるので長期試験む可能 である,

などの特徴がある。うかし，厳密な意味で参照電極を用 いることが難しく，七ル内で起こる色々な変化を直接観 察することができない，などの久点があるので，目的に 灿じてフラッデッド三電極セルと密閉加压式一電極セル を使い分ける必要がある。

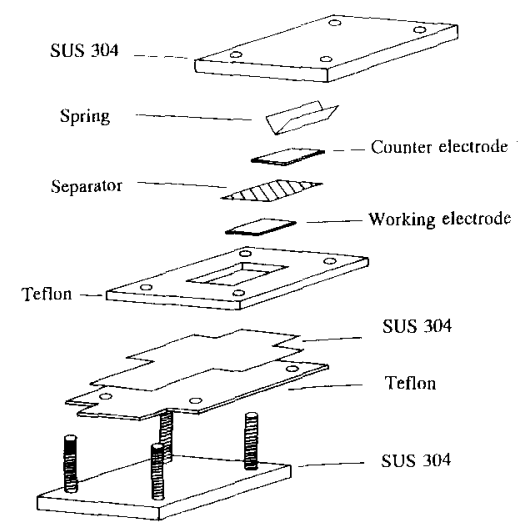

Fig. 1 Schematic illustration of a cell used to examine insertion materials. 


\section{5 リチウムインサーション材料の}

電気化学測定法と実施例

\section{1 可逆電極試験（充放電試験）}

インサーション材料の可逆電極機能を基礎的な立場か ら検討するためには，ポテンショ又夕ット（ガルバノス タット)，ファンクションジェネレーター，(アナログま たはデジタル）レコーダーなどの基本的な電気化学測定 装置に加えて充放電試験装置が必要である。 Fig. 2 に 簡便な充放電試験装置の基本回路 ${ }^{22}$ を示す。この装置 を用いて一定時間の充放電, 設定した上限電压と下限電 圧の間での充放電，あるいはこれらを組み合わせたモー ドの充放電試験ができる，この基本回路は,リレースイッ 千, 定電流電源なよ゙の回路が組み这まれていないので, たとえば定電流連続充放電, 定電流間久充放電の場合に は, 別に定電流電源, タイマー回路などが必要である ${ }^{13)}$. また，充電を定電流-定電圧モードで一定時間行いたい 場合には, ポテンショスタット・ガルバノスタットの基

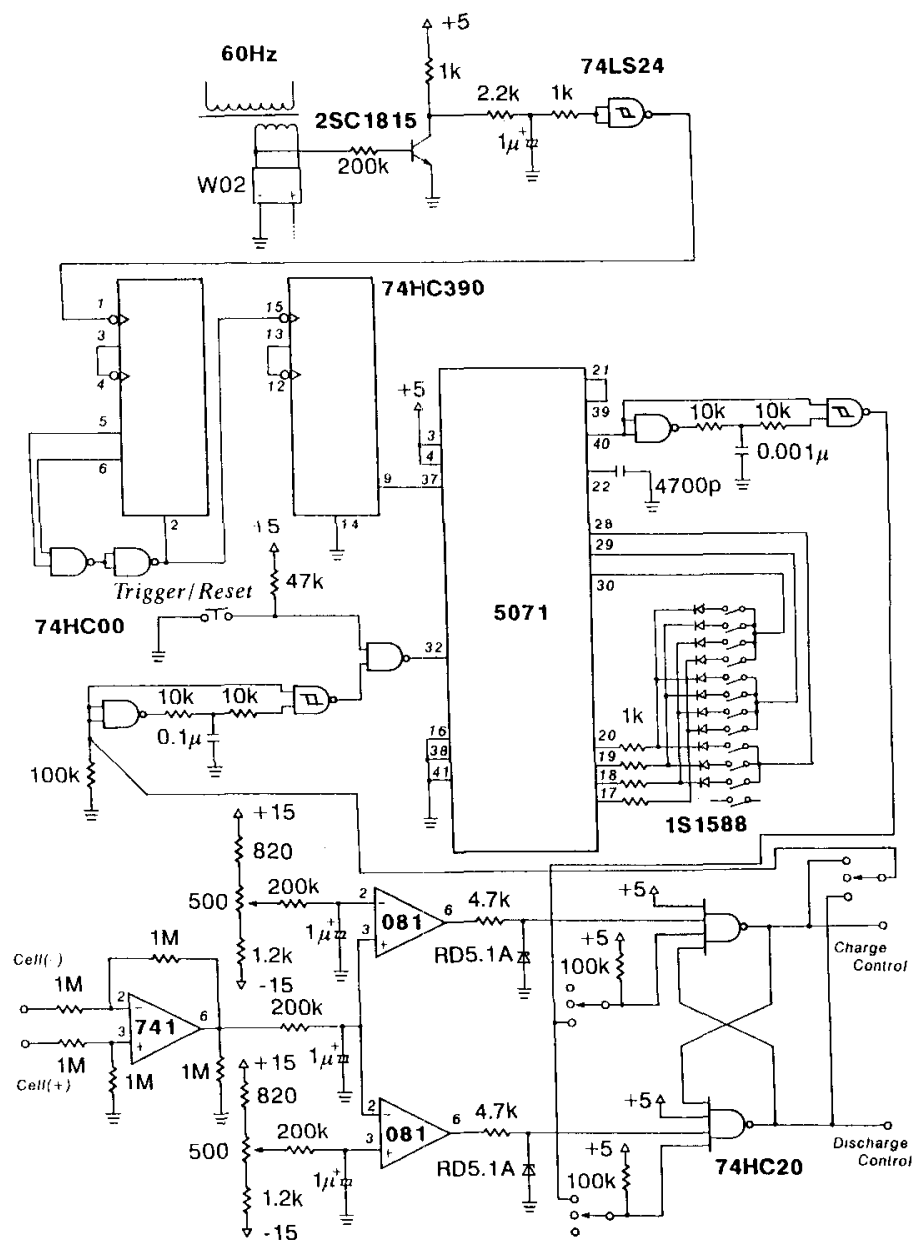

Fig. 2 Circuit diagram of a cell cycler.
本回路を用いた定電流-定電圧電源が別途必要である. この充放電装置に定電流電源を組み合わせ，Fig. 10 密閉加圧式二電極セルを用いて测定した $\mathrm{LiNiO}_{2}$ $(\mathrm{R} \overline{3} \mathrm{~m})$ のデータ ${ }^{14)}$ の一例を Fig. 3 に示す．定電流で 一定時間充電 $\left(\mathrm{LiNiO}_{2}\right.$ 当たり $150 \mathrm{mAh} \cdot \mathrm{g}^{-1}$ の定容 量充電）した後，同じく定電流で $2.5 \mathrm{~V}$ の終止電圧まで 放電して，このモードで充放電を繰り返したものである. これは，一種の定容量充電-定電流放電試験に相当する. 一方，インサーション材料の電池機能材料としての適用 性を検討する場合には，充電終止電圧と放電終止電圧を 設定し，定電流条件での充放電試験が多く用いられる。

この場合には，Fig. 2 の上半分の回路構成は不用であ るので更に簡略化される ${ }^{13,15)}$ 。これらの測定装置もで きれば自作し，装置をブラックボックスとして用いるの ではなく, 電気化学システムとして位置づけ, 後述する ようにシステムの曖昧さを理解した上で電気化学情報 （電圧, 電流, 容量)を集積することが何よりも必要で あ万う。

\section{2 ボルタンメトリー}

電極材料の可逆性扔よび電気化学反 応の質を短時間で評価できるところか らインサーション材料を検討する際に あボルタンメトリーが多用される傾向 にある。しかし，インサーション反応 の特徽からボルタンメトリーのみの情 報でインサーション反応を解明するこ とは難しく, 例えば材料の迅速な予備 的検討, 材料の酸化・還元の繰り返し によるボルタンモグラムの形状の変化 を追跡するなど，目的をある程度限定 し，他の測定法と併用することによっ てのみこの迅速測定法の威力が発揮さ れる. Fig. 4 にLT-LiMnO 2 の酸化・ 還元 ${ }^{16)}$ の繰り返しによってボルタン モグラムが，どのように変化するかを 追跡する目的で行った結果の一例を示 す. $\mathrm{LT}^{-}-\mathrm{LiMnO}_{2}$ は本来可逆的な挙 動を示さず，酸化・還元の繰り返しに よって明確な一対の酸化・還元ピーク を示し, 全く別の反応系にシフトして いることが，このボルタンメトリーか らわかる.このボルタンメトリーをイ ンサーション材料を取り扱う電気化学 測定法の一手法上するためには，電圧 を低速掃引できるファンクションジェ ネレーターとドリフトの少ないポテン ショスタットならびにアナログ式の X-Yレコーダーを必要とする. また, 


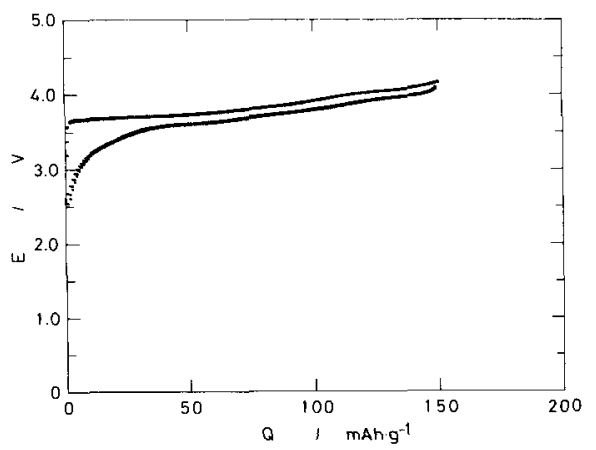

Fig. 3 Charge and discharge curves for a $\mathrm{Li} /$ $\mathrm{LiNiO}_{2}$ cell under a constant charge capacity of $150 \mathrm{mAh} \cdot \mathrm{g}^{-1}$ followed by discharge to $2.5 \mathrm{~V}$ at a rate of $0.17 \mathrm{~mA}^{\prime} \mathrm{cm}^{-2}$ at $30^{\circ} \mathrm{C}$. Electrolyte used was $1 \mathrm{M} \mathrm{LiClO}_{4}$ dissolved in propylene carbonate. In drawing curves the first cycle was discarded.

目的に適った情報がボルタンメトリーによって正確に得 られるにように電極構造を工夫することあ必要である.

5.3 インピーダンス測定法

近年の電子機器の発達でインピーダンス測定も以前に 比べて容易になり, 得られた結果の表示をも含めて汎用 化が進んでいる，得られたインピーダンスの測定結果は, 通常 Cole-Cole プロットと呼げれる周波数を媒関数と した複素平面上の軌跡で表され ${ }^{17)}$ ，系を等価回路で表 した時のパラメーターと解析式との対応関係から電気二 重篔容量, 交換電流密度, 拡散係数なよ゙のパラメーター が求められる。方，インピーダンス（スペクトロスコ ピー）には，電極系の電压（反応の質）に関わる情報を 除いてほぼすべての情報が合まれていることから，等価 回路モデルに頼ることなくインピーダンスのデータから ボルタンメトリー，クロノポテンシオメトリー（定電流 充放電）などの一連の電極挙動を予測しようとする試み がある ${ }^{18)}$.インサーション材料の研究にこの考え方を 用いると、インサーション電極の動的なキャラクタ一や, インサーション材料の組み合わせからなる電池の充放電 挙動, 出力特性, 内部抵抗に起因する寿命などを予測す ることが可能となるので，近年，一連のインサーション 材料の研究にこの新しいインピーダンススペクトロスコ ピーの概念が導入され始めている。

\section{4 その他の測定法}

電気化学測定のみでは, インサーション材料の固相酸 化・還元反心の様式を明らかにすることができないので, 通常, 電気化学的な情報と他の測定法によって得られた 情報とから反伈機構が推定される。一般的な材料の分析 手法には，X線，中性子線，電子線，光，熱，磁力な どを利用した多くの方法がある.しかし，インサーショ

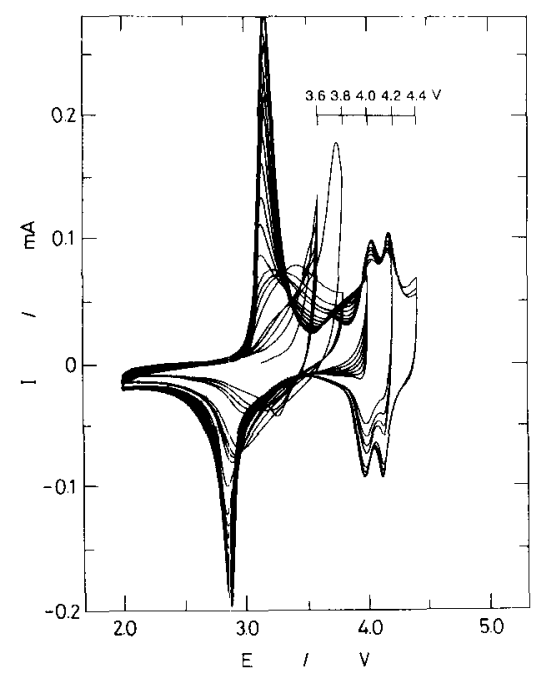

Fig. 4 Window-opening experiments on the cyclic voltammogram of $\varepsilon \mathrm{Li} / \mathrm{LT}-\mathrm{LiMnO}_{2}$ cell at a sweep rate of $0.1 \mathrm{mV} \cdot \mathrm{s}^{-1}$.

ン材料の固相酸化・還元反它で生成した物質の情報を 「生きたまま」検出できる測定法となると結晶性固体の 場合には，今のところ粉末 X 線回折法に限定される.

$\mathrm{X}$ 線は, 大気中を伝搬し, 現用の有機系電解液による 吸収も少なく，しか子電極試料へのX 線進入深さもミ クロンオーダーなので, 電気化学的な情報之対応関係に ある「生きたまま」の物質の（バルク結晶）構造に関す る情報が得られる.このX 線回折法と電気化学測定法 を組み合わせて「その㙏」测定が可能なセルが考えられ ている.この場合, 電極の配置, ベリリウムなよ゙の空と の間隙，電流分布，再現性などを充分検討しなければ 「その場」の情報を提供してくれるものの本来の電気化 学的な情報との対応関係を取り難くなることもある。ま た，インサーション材料を有機系電解液中で電解酸化・ 還元させて調製した試料を高真空系を必要とする分析法 のチャンバーに導入すると，その粒子形態をむ含めて化 学組成などが变化する場合が多く, 非水環境卜で存在し 得た興味樑い物質のキャラクターを見失うこと屯あるの で，その使用にあたっては細心の注意を要する。

Fig. 5 にインサーション反応を別な観点から眺める ために行った「その場」測定の結果の一例を示す ${ }^{19)}$.

この方法は，電気化学測定法とアコースティックエミッ ション（スペクトロスコピー）法とを組み合わせたもの である.インサーション反応の進行に伴って，二酸化マ ンガン粒子の脆性破壊に起因する「音」が検出されてい ることがわかる。この「その場」测定法は, 結晶性固体 に限定される向のではなく，X線回折法が適用できな かった（溶融）スラグなどのガラス質系無機材料に対し 


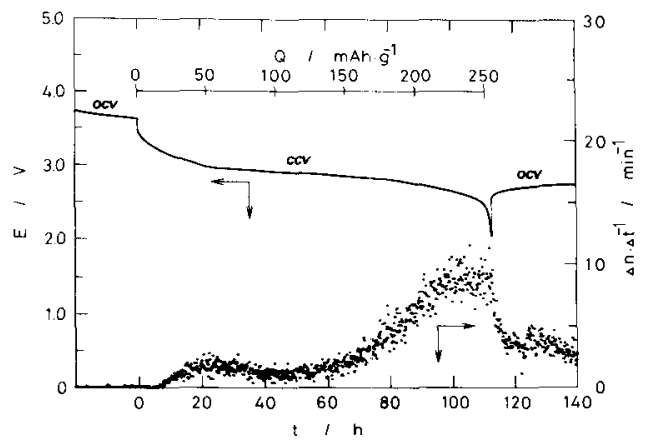

Fig. 5 Discharge curve of electrolytic manganese dioxide (FMD) in a nonaqueous lithium cell and the rate of event per minute in terms of acoustic emission. Electrolyte used was $1 \mathrm{M} \mathrm{\textrm {LiClO } _ { 4 } \mathrm { PC } /}$ DME ( $1 / 1$ by volume).

ても適用できる。このようにインサーション材料固有の 電極兴動を理解し，固体電気化登を更に発展させるため には，新しい視点にウった「その場」测定法が，今後さ らに必要亡なる屯のと思われる。

\section{6 自動計測システムの構筑と問題点}

十数年前までは, リチウムインサーション材料に限ら ず電池機能材料の允放電試験は，Fig. 2 の充放電試験 装置, 定電流電源, 多点式（アナログ）レコーダーを用 いて行っていた。こ机はは，時間と䇰力を要したので一 度に多くの材料试験を古ることが困難で，研究の効率を あげるには自ずと限界があった。最近ではパーソナルコ ンピューターを用いて(電圧) データの数值化, 保存, そして任意の作㼟客易に行うことができるようになっ た. Fig.6に (天然) 黑鉛の充放電曲線をディジタル 記録し，電玨之充電 (放電) 電㸚量で表した充放電曲線 上, (充電・放電) 電気量を電压で数值微分 $(\mathrm{dQ} / \mathrm{dF})$ した後，これを電なに対してプロットした，いわゆる微 分クロノポテンショグラム ${ }^{20)}$ を示す。この微尔ク口， ポテンショグラムとボルタンモグラムとは基本的に同じ 電気化学楻応の情報を与えてくれる.しかし，通常ボル タンモグラムを測定する際には，試料を極微量とするな ど電極構成に工夫を要するので, 多くの場合, 酸化・還 元ピークの帰属が曖昧となる。したがって，化学組成 （充電・放電電気量）と粉末 X 線回折法による結晶構造 の相関から電気化学反応の質定見きわめようとした場合 には，微分クロノポテンショグラムによって電父化学的 なデータと構造化学的なデー夕を補間し，5.2で述べた ボルタンメトリーによって吏に搉認することが必要であ ろう.

電気化学系から得られる一次情報が, 電玨あるいは電
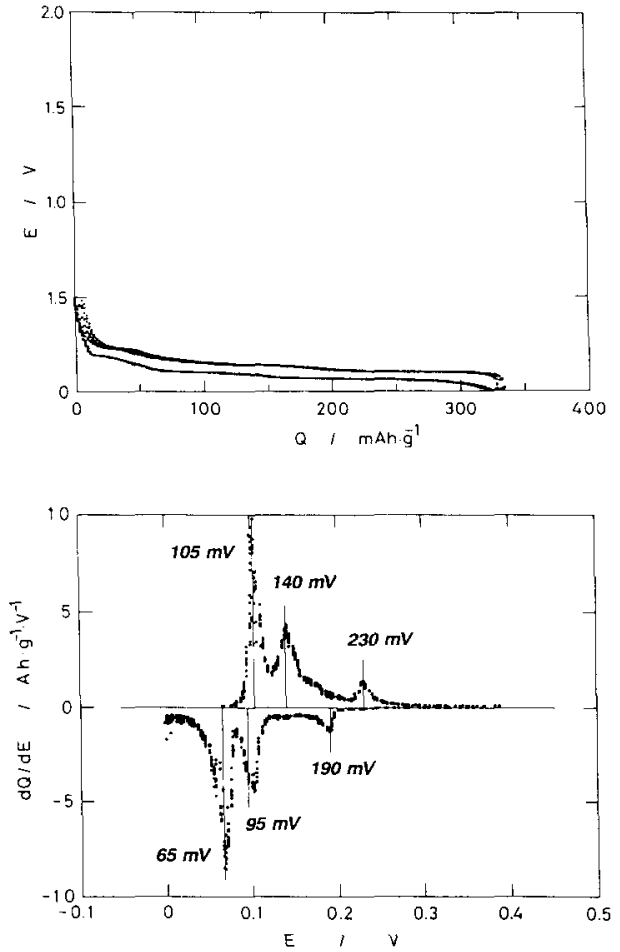

Fig. 6 An electrochemical behavior of natural graphite (NG-7) electrode in $1 \mathrm{M} \mathrm{LiClO}_{4} \mathrm{EC} / \mathrm{DME}$ $\left(1 / 1\right.$ by volume) at $30^{\circ} \mathrm{C}$; (a) charge (reduction) and discharge (oxidation) curves at a rate of 0.17 $\mathrm{mA} \cdot \mathrm{cm}^{-2}$ in the voltage range between $0.0 \mathrm{~V}$ and $0.5 \mathrm{~V}$ vs. Li, (b) differential chronopotentiograms on the reduction and oxidation of lithiated graphite.

流であることから，測定系を今む電気化学测定システム によ゙の程度の暧味さが含まれているかを吟味しておく必 要がある。この曖昧さは，オフセットエラー,リニアリ ティエラー, ADコンバータの分解能・ゼロドリフトな どさまざまである，たとえば，1\%の䛊差は，通常許容

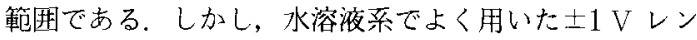
ジからリチウム非水溶媒系でよく用いる士5 V（フルス ケール $10 \mathrm{~V})$ レンジにシフトさせた場合，その $1 \%$ 䛊 差は最大 $100 \mathrm{mV}$ の蔓昧さを意味する。この場合にも デジタル表示では, $0.1 \mathrm{mV}$ までの数值として与えられ， あたかむ $0.1 \mathrm{mV}$ の精度があると錯覚してしまうので注 意を要する。また，長期にわたる测定を行う場合には， これに加えて测定装置のドリフトが時として問題となる。 その一例として，ディジタル関数発生器とポテンショス タットを組み合わせたシステムのドリフトを測定した結 果をFig.7 に示す，設定電圧を「画面上 $3.000 \mathrm{~V} 」 と$ した時の実際の制御電压と，室温変動を別途測定したむ 


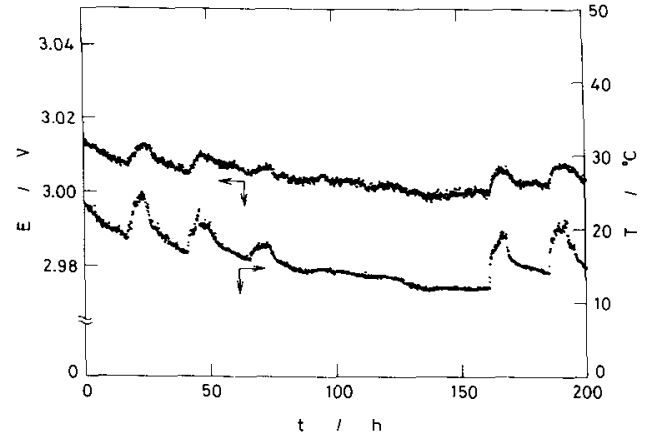

Fig. 7 A drift of dc-bias voltage due to a change in (room) temperature.

のである，琼定值 $3.000 \mathrm{~V}$ に対して初期 $3.013 \mathrm{~V}$ （設定 值に対して $0.4 \%$ 誤差) で，その温度ドリフトは約 1 $\mathrm{mV} /{ }^{\circ} \mathrm{C}$ であった。この暧昧さが訢容範䎴かどうかは，

目的によって異なる。しかし，設定電圧は「画面上

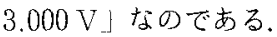

\section{7 おわりに}

リチゥムインサーション材料は, 固体電気化学を展開 する上で興味深い多くの現象を提供してくれる。この固 体電父化学は, 電気化学, 無機構造化学, 固体物理学, セラミックス材料化学とを融合させた新しい分野である. このインサーション材料を組み合わせることによってり チウムイオン蓄電池とすることができるので，近年，そ の研究開発が活発である。このインサーション材料の持 つ潜在的な能力を更に発揮させるためにも，今後益々材 料のキャラクターを見きわめるための新しい測定法が期 待さ机る。本稿が，リチウムインサーション材料に関す る研究手法の一助となれば幸いである。

\section{文献}

1) 武井 武編, 夷験電気化学, 丸善 (1955)

2）吉澤四郎編，電気化学実験法，いずみ書房 (1971)

3）電気化学協会編, 電気化学測定法, 電気化学協会 (1972).

4) 藤嶋 昭, 相澤益男, 非上 徹著, 電気化学測定法 (上) (下)，技報堂 (1984)

5）卡虫伶太著, 電気化学, 東京化学同人（1991）.

6) T. Ohzuku and A. Ueda, Solid State Ionics, 69, 201 (1994).

7) 小槻 勉，第24 [回電気化学講習会テキスト，pp. 85-94, 電気化学協会関西支部 (1994).

8) T. Ohzuku, I. 'Tari and T. Hirai, Electrochim. Acta, 26,1423 (1981)

9）小柣勉，竹原善一郎，吉澤四郎，電気化学，46，407, 411 (1978)

10) T. Ohzuku and T. Hirai, Electrochim. Acta, 27, 1263 (1982).

11) T. Ohzuku, M. Kitagawa and T. Hirai, J. Electrochem. Soc, 136, 3169 (1989).

12）小窥 勉，原田雅裕，澤井圭二郎，電気化学協会秋季人 会講演要旨集, p. 201, 福岡 (1993).

13）小炾 勉, 竹原善一郎, 吉澤四郎，電気化学， 46，640 (1978).

14) T. Ohzuku, A. Ueda and M. Nagayama, J. Electrochem. Soc., 140, 1862 (1993).

15) T. Ohzuku, A. Ueda and M. Kouguchi, J. Electrochem. Soc., 142, 4033 (1995).

16) T. Ohzuku, A. Ueda and T. Hirai, Chemistry Express, 7, $193(1992)$

17) K. Sawai, Y. Iwakoshi and T. Ohzuku, Solid State Ionics, 69, 273 (1994).

18）澤井丰二郎，小柣 勉，第 36 回電池誩論会要旨集， p. 103，宗都 (1995).

19）小柣 兔，广村裕彦，澤井圭二郎，電気化学会第63回大 会講演要旨集, p. 119, 東京 (1996).

20) T. Ohzuku, M. Kitagawa and T. Hirai, $J$. Electrochem. Soc., 137, 40, 769 (1990). 